\title{
A INFORMAÇÃO A SERVIÇO DA REPRESSÃO NAS UNIVERSIDADES: ASSESSORIA DE SEGURANÇA E INFORMAÇÕES DA UFRN (ASI/UFRN) - NOS RASTROS DO RELATÓRIO FINAL DA COMISSÃO DA VERDADE
}

\author{
Maria Elizete Guimarães Carvalho ${ }^{1}$ \\ Rogério de Araújo Lima²
}

\begin{abstract}
Resumo
Lançado em 14 de outubro de 2015, o Relatório Final da Comissão da Verdade da Universidade Federal do Rio Grande do Norte (UFRN) esboça um quadro historiográfico preocupante acerca da atuação do regime militar nessa instituição de ensino superior, com destaque para a Assessoria de Segurança e Informações da UFRN (ASI/UFRN). Nesse sentido, o presente trabalho tem o propósito de refletir sobre a cooperação existente entre as universidades e a comunidade de informação do regime militar para fins de monitoramento da vida acadêmica. Para tanto, partiu-se da realidade vivida pela comunidade acadêmica da Universidade Federal do Rio Grande do Norte (1971-1990), que, por intermédio do esforço investigativo da Comissão da Verdade da UFRN (CV-UFRN), relata histórias e memórias sobre as ações da ASI/UFRN. Alicerçando-se nas formulações teórico-metodológicas de Motta (2014, 2008a), Halbwachs (2003) e Ginzburg (1989), dentre outros, este ensaio contempla o indiciarismo como modelo epistemológico, a história oral como metodologia e a memória coletiva como categoria de análise. A partir das impressões, vivências e subjetividades dos agentes sociais participantes da pesquisa, tem-se que a ASI/UFRN, bem como as demais assessorias, embora não fosse e, legalmente, não pudesse ser, órgão de repressão, agiu a serviço e em função da máquina repressora do estado militar, ao efetivar, sob o pálio do medo, o controle ideológico, a censura e o expurgo no âmbito das Instituições de Ensino Superior.
\end{abstract}

Palavras-chave: Relatório final da comissão da verdade da UFRN. Assessoria de segurança e informações. Instituições de ensino superior. Ditadura Militar.

\section{INFORMATION ON THE OF SERVICE REPRESSIONE IN UNIVERSITIEA: UFRN (ASI/UFRN) SECURITY AND INFORMATION ADVISORY - IN THE TRAILS OS THE FINAL REPORT OF THE TRUTH COMMISSION}

\begin{abstract}
Released on October 14, 2015, the Final Report by the Truth Commission from the Federal University of Rio Grande do Norte (UFRN) outlines a disturbing historiographical picture about the performance of the military regime in this institution of higher education, especially the Security and Information Advisory from UFRN (ASI/UFRN). In this sense,
\end{abstract}


the present work has the purpose of reflecting on the existing cooperation among the universities and the information community of the military regime with the purpose of monitoring the academic life. For that, it was based on the reality lived by the academic community of the Federal University of Rio Grande do Norte (1971-1990), which, through the investigative effort of the Truth Commission from UFRN (CV-UFRN), reports stories and memoirs about the actions of ASI/UFRN. Based on the theoretical-methodological formulations of Motta (2014, 2008a), Halbwachs (2003) and Ginzburg (1989), among others, this essay contemplates indiciarism as an epistemological model, oral history as a methodology and collective memory as a category of analysis. Based on the impressions, experiences and subjectivities of the social agents participating in the research, it is concluded that ASI/UFRN, as well as other advisory services, although they weren't and, legally, they couldn't be, a repression agency, they acted in the service and in function of the repressive machine of the military state, by effecting, under the canopy of fear, ideological control, censorship and purging within the scope of Higher Education Institutions.

Keywords: Final report by the truth commission from UFRN. Security and information advisory. Higher education institutions. Military Dictatorship.

\title{
LA INFORMACIÓN A SERVICO DE LA REPRESIÓN EN LAS UNIVERSIDADES: ASESORÍA DE SEGURANZA Y INFORMACIONES DE LA UFRN (ASI/UFRN): EN LOS RASTROS DEL INFORME DE LA COMISIÓN DE LA VERDAD
}

\begin{abstract}
Resumen
Lanzado al 14 de octubre de 1915, el Informe Final de la Comisión de la Verdad de la Universidade Federal do Rio Grande do Norte (UFRN) esboza un cuadro historiográfico preocupante acerca de la actuación del régimen militar en esa institución de enseño superior, con destaque para la Asesoría de Seguranza y Informaciones de la UFRN (ASI/UFRN). En ese sentido, el presente estudio tiene el propósito de reflexionar sobre la cooperación existente entre las universidades e a comunidad de información del régimen militar para finalidades de monitoria de la vida académica. Para tanto, se partió de la realidad vivida por la comunidad académica de la Universidade Federal do Rio Grande do Norte (1971-1990), que por intermedio del esfuerzo investigativo de la Comisión de la Verdad de la UFRN (CVUFRN), relata historias y memorias sobre las acciones de la ASI-UFRN. Basándose en las formulaciones teórico-metodológicas de Motta (2014, 2008a), Halbwachs (2003) e Ginzburg (1989), entre otros, este intento contempla el indiciarismo como modelo epistemológico, la historia oral como metodología y la memoria colectiva como categoría de análisis. Partiendo de las impresiones, vivencias y subjetividades de los agentes sociales participantes de la pesquisa, se tiene que la ASI-UFRN, así como las demás asesorías, aunque no fuera y, legalmente, no pudiera ser, órgano de represión, actuó a servicio y en función de la máquina represora del estado militar, al hacer efectivo, abajo del palio del
\end{abstract}


medo, el control ideológico, la censura y el expurgo en el ámbito de las Instituciones de Enseño Superior.

Palabras-clave: Informe final de la comisión de la verdad de la UFRN. Asesoría de seguranza y informaciones. Instituciones de enseño superior. Dictadura Militar.

\section{INTRODUÇÃO}

Fundamentado em motivações políticas, ideológicas e econômicas, o novo bloco de poder instaurado no Brasil a 31 de março de 1964, fruto de um golpe civil-militar que duraria longos 21 anos e que entraria para a história como um dos períodos de maior violação aos direitos humanos, antes mesmo de definir os rumos que daria ao país, tinha na cooptação ou eliminação dos derrotados o seu primeiro desafio, de maneira que "[...] depois dos sindicatos e das organizações de trabalhadores rurais, as instituições universitárias foram alvos prioritários das ações repressivas." (MOTTA, 2014, p. 23). As consequências imediatas foram: invasões e ocupações, nomeação de reitores militares, expurgos, aposentadorias compulsórias, violência física e psicológica, sumiço e até morte de professores e alunos.

Diante de atrocidades como tortura, asilo forçado e mortes, as análises historiográficas que compreendem a periodização que vai de 1964 a 1985 têm dado o merecido destaque a esses acontecimentos mais gravosos do ponto de vista da violação dos direitos humanos. O que não se pode perder de vista, nesse contexto, é que para torturar, expurgar, violentar psicológica e fisicamente e, inclusive, matar, o regime autoritário criou uma comunidade de informação que possuía tentáculos em praticamente todos os órgãos públicos presentes em todos os rincões do país. Tal comunidade de informação tem despertado mais recentemente o interesse de pesquisadores em função do acesso a dossiês e documentos que traduzem o modus operandi da ditadura militar no monitoramento dos agentes públicos e cidadãos que possuíam qualquer tipo de vínculo com autarquias e fundações públicas, no âmbito das quais se acham inseridas as universidades.

Não é exagero dizer que um dos mais eficazes sistemas de informação já concebido no Brasil se deu exatamente no contexto da ditadura civil-militar. Pesquisas recentes confirmam essa assertiva, ao constatar que "Juntos, $\mathrm{SNI}^{3}, \mathrm{CIE}^{4}$, $\mathrm{Cisa}^{5}$ e Cenimar ${ }^{6}$ formavam a cúpula do sistema de informações da ditadura" (FIGUEIREDO, 2015, p. 18), tendo gerado riquíssimo acervo iconográfico e documental e se utilizado, inclusive, do mais avançado método disponível à época: a microfilmagem. Acerca desta, sabe-se que:

Exército, Marinha e Aeronáutica investiram pesadamente na microfilmagem de seus arquivos e ainda guardavam boa parte dos originais em papel. Isso fazia com que cópias de um mesmo documento fossem simultaneamente preservadas pela CIE, pelo Cenimar e pelo Cisa, e muitas vezes em duplicata (papel e microfilme). Como de costume no meio militar, essa profusão de registros era armazenada de forma extremamente organizada. Tudo era formalizado. Ao serem guardados em 


\section{Revista HIIST'TEIDBR On-line}

pastas (no caso de papéis) ou em jaquetas (envelopes de acetato para acondicionamento de microfilme), os documentos eram também catalogados. Um papel ou microfilme sigiloso podia repousar por décadas ou até mesmo para sempre no fundo de um armário. (FIGUEIREDO, 2015, p. 42).

Mas onde repousam tais fontes? Como acessá-las? A quem recorrer para examinálas? Esses são questionamentos ainda em aberto mesmo diante das inúmeras tentativas de governos, da sociedade civil organizada e de instituições públicas no intuito de acessar os documentos sob a guarda das Forças Armadas do Brasil.

A esse respeito, praticamente todas as vezes que foram instadas a se pronunciar sobre os arquivos da repressão, quer seja no contexto da retomada do regime democrático pós 1985, quer seja no contexto das demandas recentes da Comissão Nacional da Verdade, as Forças Armadas posicionaram-se pela negativa da existência de arquivos comprobatórios das ações do regime militar à estratégia constrangedora do reconhecimento de sua destruição sem o respectivo registro de acontecimento tão relevante do ponto de vista histórico. Assim, "Em um movimento sincronizado, Exército, Marinha e Aeronáutica passaram a alegar que os documentos sigilosos relativos à repressão tinham sido destruídos, em época desconhecida, em operações rotineiras de limpeza de arquivo" (FIGUEIREDO, 2015, p. 65), como se apagar 21 anos de história das Forças Armadas no Brasil fosse um episódio trivial ${ }^{7}$.

A impressão que se tem, quanto às informações de interesse histórico acerca da atuação do regime militar no Brasil (1964-1985), é a de que mesmo depois de findos os mandatos de seis presidentes civis pós-ditadura ${ }^{8}$, modificada a legislação sobre os arquivos públicos ${ }^{9}$ e instituída a Comissão Nacional da Verdade ${ }^{10}$, "Exército, Marinha e Aeronáutica já não mandavam. Mas também não obedeciam.” (FIGUEIREDO, 2015, p. 65).

Há, no entanto, pistas, rastros deixados involuntariamente pelas forças Armadas, que se encontram fora dos quartéis e que permitem esboçar cenários possíveis relativos ao binômio informação-repressão. São exemplos os documentos depositados no acervo do Arquivo Nacional ou "esquecidos" em algumas instituições, resultados da paradoxal logística de monitoramento e preservação dos acervos produzidos na/pela própria comunidade de informação:

\footnotetext{
Os cuidados tomados pela "comunidade" para afastar dos olhos do público os "seus" arquivos, felizmente, não foram totalmente bem sucedidos. Além dos arquivos preservados em algumas universidades, centenas de documentos produzidos pelas ASI estão guardados no fundo do SNI, agora abertos à consulta pública no Arquivo Nacional, e há também muitos registros nos acervos dos Departamentos de Ordem Política e Social de alguns Estados. É o resultado paradoxal do próprio trabalho das agências de repressão, que disseminavam entre si os documentos por necessidade do serviço. (MOTTA, 2008a, p. 63).
}

Assim, mesmo diante da negativa de existência de documentação escrita, iconográfica e oral por parte das Forças Armadas, verificou-se que instituições que atuaram em parceria com o regime militar, voluntariamente ou não, poderiam dispor de alguns 
registros do sistema de informação e repressão. É o caso, por exemplo, das universidades, cujo cotidiano passou a ser objeto de vigilância, monitoramento e ingerência da ditadura civil-militar, tendo sido criado um órgão exclusivamente para tal fim: as Assessorias de Segurança e Informações (ASI).

Esse modelo de monitoramento da vida acadêmica nas Instituições de Ensino Superior será objeto da discussão aqui proposta, partindo-se da realidade vivenciada pela comunidade acadêmica da Universidade Federal do Rio Grande do Norte (UFRN) entre os anos de 1971 e 1990 por meio do braço informacional do regime militar nessa instituição: a Assessoria de Segurança e Informações da UFRN (ASI/UFRN).

\section{NOS RASTROS DA ASI: ASPECTOS TEÓRICO-METODOLÓGICOS}

Para dar prosseguimento à pesquisa e conduzi-la a bom termo, lançamos mão das formulações teórico-metodológicas de Motta (2014, 2008a, 2008b), Meihy; Holanda (2014), Halbwachs (2003) e Ginzburg (1989) e adotamos o indiciarismo como modelo epistemológico, a história oral como metodologia e a memória coletiva como categoria de análise.

O indiciarismo ginzburguiano foi um importante achado teórico-metodológico desta pesquisa. A partir dele e, claro, das categorias teóricas que dialogam com o paradigma indiciário, foi possível compreender que pistas, sinais, traços e vestígios poderiam resultar em importantes instrumentos de verificação da realidade vivida pela comunidade acadêmica que foi alvo das ações da ASI/UFRN.

A propósito, foi em "Sinais: raízes de um paradigma indiciário" (GINZBURG, 1989, p. 143-179), que encontramos a chave para o desenlace da investigação. A multicitada passagem em que Ginzburg (1989) resume as premissas do paradigma indiciário, atribuindo ao saber venatório status de patrimônio cognoscitivo, é digna de reapreciação. Referindo-se ao "caçador" que, intuitivamente, realiza uma verdadeira "pesquisa" para alcançar sua presa, o historiador italiano assegura que:

\footnotetext{
Por milênios o homem foi caçador. Durante inúmeras perseguições, ele aprendeu a reconstruir as formas e movimento das presas invisíveis pelas pegadas na lama, ramos quebrados, bolotas de esterco, tufos de pelos, plumas emaranhadas, odores estagnados. Aprendeu a farejar, registrar, interpretar e classificar pistas infinitesimais como fios de barba. Aprendeu a fazer operações mentais complexas com rapidez fulminante, no interior de um denso bosque ou numa clareira cheia de ciladas. Gerações e gerações de caçadores enriqueceram e transmitiram esse patrimônio cognoscitivo. (GINZBURG, 1989, p. 151).
}

Esse trecho de "Sinais" pode muito bem ser transplantado para o ato da pesquisa historiográfica, na qual o historiador vai à "caça" das suas fontes históricas. Mas é óbvio que "Uma coisa é analisar pegadas, rastros, fezes [...], catarros, córneas, pulsações, campos de 


\title{
Revista HIISTEYIDIR On-line
}

neve ou cinzas de cigarro; outra coisa é analisar escritas, pinturas ou discursos." (GINZBURG, 1989, p. 171).

Ampliando o debate a partir da advertência de que a decifração e leitura das pistas dos animais não passam de metáforas e que, portanto, não poderiam ser tomadas ao pé da letra, Ginzburg (1989) conduz o leitor/pesquisador ao universo de um indiciarismo mais elaborado (ou menos intuitivo), desenvolvido no campo da história da arte. Trata-se da análise dos textos de um estudioso russo chamado Ivan Lermonlieff, codinome de Giovanni Morelli, médico italiano cujos escritos sobre a pintura artística daquele país resultaram no modelo analítico que ficou conhecido como "Método Morelliano". Nessa linha de raciocínio,

\begin{abstract}
Vejamos rapidamente em que consistia esse método. Os museus, dizia Morelli, estão cheios de quadros atribuídos de maneira incorreta. Mas devolver cada quadro ao seu verdadeiro autor é difícil: muitíssimas vezes encontramo-nos frente a obras não-assinadas, talvez repintadas ou num mau estado de conservação. Nessas condições, é indispensável poder distinguir os originais das cópias. Para tanto, porém (dizia Morelli), é preciso não se basear, como normalmente se faz, em características mais vistosas, portanto mais facilmente imitáveis, dos quadros: os olhos erguidos para o céu de personagens de Perugino, o sorriso dos de Leonardo, e assim por diante. Pelo contrário, é necessário examinar os pormenores mais negligenciáveis, e menos influenciados pelas características da escola a que o pintor pertencia: os lóbulos das orelhas, as unhas, as formas dos dedos das mãos e dos pés [...]. (GINZBURG, 1989, p. 144).
\end{abstract}

Às voltas com lóbulos das orelhas, unhas, contornos dos dedos das mãos e dos pés etc., Morelli revolucionou a análise das obras de arte em sua época e, mais do que isso, exerceu forte influência sobre o trabalho de grandes personalidades, tais como Sigmund Freud e Arthur Conan Doyle. Neste último, escritor e criador do mais famoso detetive de toda a história, a influência do Método Morelliano é inquestionável. Sherlock Holmes, personagem de Doyle, “[...] lia nas pistas triviais e nos vestígios marginais as soluções para as intrigas detetivescas das suas histórias. Holmes, em um dos livros de Doyle, também citava Morelli.” (LIMA, 2006, p. 334).

Tal como Doyle, orientados pelo indiciarismo, pelas margens, observando traços, pistas e sinais, colhendo resíduos e restos, lançamo-nos em busca de fontes que permitissem reconstituir o passado da ASI/UFRN (1971-1990). O ponto de partida foi o Relatório Final da Comissão da Verdade da UFRN, cujos rastros passamos a seguir. Empregado na linguagem comum como sinônimo de pisada, pegada, vestígio, marca, pista, resquício ou trilha, o substantivo "rasto" [ou rastro] será empregado aqui no seu sentido figurado, ou seja, como “[...] aquilo que leva a alguém ou a algo; indício, sinal." (HOUAISS, VILLAR, 2009, p. 1613). Dessa forma, os rastros são os indícios que (per)seguimos consultando as fontes e ouvindo os colaboradores formais e informais. 
No tocante à escolha da história oral como metodologia, essa se justifica pelas características da pesquisa, cujo conteúdo traz como requisito o direito de livre expressão, que fora negado pelo regime militar, e privilegia a memória oral.

Nas ditaduras, o simples ato de falar livremente de si, sobre os outros ou acerca de acontecimentos do tempo presente é algo praticamente fora de questão. Se a oralidade, “[...] vertida em depoimentos e tradições, relatos e histórias de vida, narrações, recordações, memória e esquecimentos" (LOZANO, 2006, p. 18), é matéria-prima do historiador oral, este, para exercer a contento o seu ofício, além de oferecer uma escuta, necessita que alguém se proponha a falar/rememorar.

Para Meihy e Holanda (2014), a democracia é, portanto, condição sine qua non para a prática da história oral nos moldes como a concebemos hoje. Reconhecem, no entanto - e com razão - que:

[...] quase que como vingança pelo silêncio imposto, foi o germe da repressão militar que acabou por excitar o aparecimento de uma história oral vibrante, contestatória e prezada por quantos a entendem como contra-história. Sem dúvida, pode-se dizer que a história oral brasileira é, inclusive, uma das alternativas para a afirmação da democracia. (MEIHY; HOLANDA, 2014, p. 111).

Verificada a possibilidade atual de falarmos livremente sobre o passado, e levandose em consideração que a história oral a ser explorada girava em torno de um tema específico - atuação da ASI/UFRN nos idos de 1971 a 1990 -, elegemos o gênero história oral temática como modelo de abordagem da história oral.

Apontada por Meihy e Holanda (2014) como uma metodologia, a história oral temática abrange projetos temáticos que "[...] devem fazer as vozes se confrontarem de maneira a promover o esclarecimento das versões e assim as superações das dúvidas que, afinal, justificam o projeto." (MEIHY; HOLANDA, 2014, p. 38).

Nessa circunstância, nada mais oportuno para os fins a que se dedicou este trabalho do que o acolhimento da história oral temática como gênero de história oral, porquanto "A contundência faz parte da história oral temática, que se explica no confronto de opiniões firmadas. Assim, por natureza, a história oral temática é sempre de caráter social e nela as entrevistas não se sustentam sozinhas ou em versões únicas." (MEIHY; HOLANDA, 2014, p. 38).

O tema do artigo, bem como as suas versões, contradições e permanências, foi analisado com a profundidade que o tempo e as fontes permitiram. Na prática, o estudo desenvolveu-se por meio da análise do estado da arte sobre as Assessorias de Segurança e Informação no Brasil, da avaliação do conteúdo do Relatório Final da Comissão da Verdade da UFRN, e da consideração/exame de algumas entrevistas.

Por fim, considerando o entrelaçamento que possui com o indiciarismo e a história oral no cerne deste ensaio, bem como a natureza coletiva das memórias colacionadas, 


\section{Revista HIISTEYIDIR On-line}

elegemos a memória coletiva como categoria de análise, orientados pelos ensinamentos de Halbwachs (2003).

O sociólogo francês, autor de renomada obra que carrega o sugestivo título de "A Memória Coletiva", ao tempo em que refuta a concepção bergsoniana ${ }^{11}$ de memória, manifesta/desenvolve o prisma sob o qual a vislumbraria, nos seguintes termos:

Para Bergson, o passado permanece inteiro em nossa memória, exatamente como foi para nós; mas certos obstáculos, em especial o comportamento de nosso cérebro, impedem que evoquemos todas as suas partes. Em todo caso, as imagens dos acontecimentos passados estão completíssimas em nosso espírito (na parte inconsciente de nosso espírito), como páginas impressas nos livros que poderíamos abrir se o desejássemos, ainda que nunca mais venhamos a abri-los. Para nós, ao contrário, o que subsiste em alguma galeria subterrânea de nosso pensamento não são imagens totalmente prontas, mas - na sociedade - todas as indicações necessárias para reconstruir tais partes do nosso passado que representamos de modo incompleto ou indistinto, e que até acreditamos terem saído inteiramente de nossa memória. De onde se conclui que, quando o acaso nos põe novamente na presença dos que participaram dos mesmos acontecimentos, neles atuaram ou a eles testemunharam ao mesmo tempo que nós, quando alguém nos conta ou descobrimos de outra maneira o que então acontecia a nossa volta, estaríamos preenchendo essas lacunas aparentes? Na realidade, o que tomamos por espaço vazio era apenas uma zona um tanto indecisa, da qual nosso pensamento desviava porque aí encontrava muito pouco vestígio. No presente, se nos indicarem com precisão o caminho que seguimos, esses vestígios se destacam, nós os ligamos uns aos outros, eles se aprofundam e se reúnem por si mesmos. Eles existem, mas estavam mais acentuados na memória dos outros do que em nós. (HALBWACHS, 2003, p. 97-9, grifo nosso).

Esse fenômeno que se ampara na recordação alheia, especialmente na do grupo do qual faz parte aquele que lembra/é lembrado, corresponde ao quadro social da memória em que "A memória do indivíduo depende do seu relacionamento com a família, com a classe social, com a escola, com a Igreja, com a profissão; enfim, com os grupos de convívio e os grupos de referência peculiares a esse indivíduo." (BOSI, 1994, p. 54). Trata-se, portanto, da memória coletiva. Depreende-se, assim, que "Halbwachs amarra a memória da pessoa à memória do grupo; e esta última à esfera maior da tradição, que é a memória coletiva de cada sociedade.” (BOSI, 1994, p. 55).

Foi essa a memória, rastreada na análise das fontes e na condução das entrevistas, que viabilizou a organização do enredo deste artigo, pois as lembranças, recordações e silenciamentos só fizeram sentido quando avaliados no contexto do grupo do qual participaram/participam os sujeitos da comunidade de destino da pesquisa: comunidade acadêmica da UFRN alcançada pelas ações da ASI/UFRN nos idos de 1971 a 1990. Assim, cada memória, cada lembrança trazida à tona ora ancorava, ora suscitava, ora elucidava outra(s) memória(s). Do entrecruzamento dessas narrativas memorialistas emergiu uma memória, e essa memória foi/é uma memória coletiva da ASI/UFRN. 


\title{
CONJUGANDO OS VERBOS INFORMAR E REPRIMIR: DA COMUNIDADE DE INFORMAÇÃO À ASSESSORIA DE SEGURANÇA E INFORMAÇÕES DA UFRN
}

Insatisfeito com o cambaleante serviço de inteligência federal em vigor, criado em 1956 e capitaneado pelo Serviço Federal de Informações e Contrainformações (Sfici), o governo militar, ciente de que tal sistema foi incapaz de prever a contento e muito menos impedir o golpe recentemente sucedido, empreendeu profundas reformas no serviço oficial de informações, extinguindo o Sfici e criando o Serviço Nacional de Informações (SNI). Além da inoperância do agora extinto Sfici, pode-se afirmar, resumidamente, que:

\begin{abstract}
A criação do Serviço Nacional de Informações (SNI), em meados de 1964, decorreu do interesse do regime militar em dispor de informações estratégicas úteis para as ações de governo, mas, também, da preocupação de precaver-se contra os inimigos recentemente derrotados, mas não aniquilados, particularmente a esquerda. Importa ressalvar que na concepção original o SNI deveria funcionar como agência de inteligência, e não como serviço de repressão ou segurança. A parte mais "contundente" da salvaguarda da segurança nacional deveria caber a outras instituições, ou seja, o trabalho de repressão aos inimigos do Estado caberia às polícias estaduais $\left(\mathrm{DOPS}^{12}\right)$ e à Polícia Federal, aos quais se uniriam mais tarde os DOI-CODI ${ }^{13}$ e os serviços de informação ligados às Forças Armadas, quando as ações militares contra os grupos de esquerda tornaram-se mais virulentas. (MOTTA, 2008b, p. 34).
\end{abstract}

Lançada a pedra fundamental que daria sustentação ao novo sistema de informação e contrainformação, dada a consolidação do golpe e o recrudescimento do regime militar nos anos seguintes, o governo autoritário achou por bem ampliar a comunidade de informação oficial, cujos tentáculos deveriam estar presentes em todos os setores que representassem de alguma forma qualquer sorte de ameaça ao regime. Esse é o contexto em que se deu a reestruturação do sistema informacional, traduzida pela criação do braço governamental nos órgãos públicos federais: as Divisões de Segurança e Informações (DSI), cuja finalidade "[...] era assessorar os titulares dos ministérios no processo de tomada de decisões e em questões de segurança." (MOTTA, 2014, p. 34).

Dentre as DSI criadas estava a Divisão de Segurança e Informações do Ministério da Educação (DSI/MEC), a quem estaria futuramente vinculada as Assessorias de Segurança e Informações (ASI) das universidades. Aperfeiçoava-se o mecanismo de informação à serviço da repressão.

Nesse contexto, ainda no florescer da década de 1970, ampliou-se a atuação do Cenimar, cuja meta "[...] era de ter capacidade de produzir informes sobre "qualquer cidadão'. Naquele momento, havia um alvo prioritário: os universitários.” (FIGUEIREDO, 2015. p. 21). Na verdade, os instrumentos de informação e controle não recaíram somente sobre o corpo discente. Não foi mera coincidência a criação nas universidades, igualmente no início da década de 1970, de órgãos de informação denominados originariamente de 


\title{
Revista HIISTEYIDBR On-line
}

Artigo

doi: $10.20396 /$ rho.v18i1.8651655

Assessorias Especiais de Segurança e Informações (Aesis) e depois de Assessorias de Segurança e Informações (ASI). Isso porque:

\begin{abstract}
Na lógica dos responsáveis pela área de segurança e repressão, o expurgo de professores e estudantes inconvenientes deveria ser seguido de constante vigilância para impedir o 'retorno' das ameaças. Daí a ideia de criar assessorias de informação dentro das instituições de ensino superior: elas seriam um 'braço' do Sistema Nacional de Informação (Sisni); funcionariam como uma espécie de correia de transmissão, fazendo chegar determinações e pressões políticas provenientes de escalões superiores; e, ao mesmo tempo, vigiariam a comunidade universitária e os próprios dirigentes, nem sempre fiéis aos desígnios do regime militar. (MOTTA, 2014, p. 193).
\end{abstract}

Então, na década de 1970, foram inauguradas assessorias dessa ordem em todas as universidades federais existentes, independentemente do alinhamento político-ideológico das reitorias com os militares no poder, até porque “[...] os reitores não podiam impedir a instalação dessas agências, mas puderam escolher entre uma colaboração irrestrita ou reticente." (MOTTA, 2008b, p. 58).

A UFRN foi das primeiras Universidades a criar internamente uma ASI, fato que remonta ao ano de 1971 e se prolonga até a sua retardada extinção no pós-ditadura, em 1990. Conforme Bueno:

\begin{abstract}
A Assessoria de Segurança e Informações da Universidade Federal do Rio Grande do Norte [...] foi criada pelo Reitor Onofre Lopes da Silva em 1971 no final da sua gestão [...]. Funcionou no Campus Universitário até meados dos anos 1980, quando foi transferida para a Delegacia do MEC no Rio Grande do Norte (DEMEC/RN), coincidindo com o período de transição ao regime democrático e, portanto, cada vez mais tendo sua atuação enfraquecida até ser extinta no início do governo Fernando Color de Mello em 1990. (BUENO, 2015, p. 85-86).
\end{abstract}

Deve-se à Comissão da Verdade da UFRN (CV/UFRN) o maior esforço investigativo realizado até o presente com o fim de proporcionar às antigas, novas e futuras gerações o conhecimento acerca da história e memória sobre a ASI/UFRN ${ }^{14}$. Depois de apelo da comunidade discente por intermédio do Diretório Acadêmico do Curso de Direito, a Comissão da Verdade da UFRN foi criada pela Portaria n ${ }^{\circ} 1.809 / 12-R$, de 31 de outubro de 2012, subscrita pela Reitora Ângela Maria Paiva Cruz, “[...] com a finalidade de efetivar o direito à memória e à verdade histórica visando a colaborar com a Comissão Nacional da Verdade da Casa Civil da Presidência da República, criada pela Lei $\mathrm{n}^{\circ} 12.528$, de 18/11/2011." (UNIVERSIDADE FEDERAL DO RIO GRANDE DO NORTE, 2012, p. 3 ).

Na conclusão dos trabalhos, no ano de 2015, a CV/UFRN dedicou os capítulos IV e $\mathrm{V}$ do Relatório Final à ASI/UFRN, capítulos esses que despertaram o nosso interesse pela busca de novas informações e que resultou na escrita deste artigo.

No capítulo IV do Relatório, Bueno (2015), membro da CV/UFRN, historiador e professor da UFRN, traçou um panorama da ASI/UFRN relacionando-o com o cenário nacional. Avaliou ainda alguns depoimentos prestados perante a CV/UFRN e, a partir dos testemunhos, fez um apanhado das fontes existentes sobre a ASI/UFRN. 


\title{
Revista HIISTEYIDIR On-line
}

No capítulo V do Relatório, Almeida (2015), membro da CV/UFRN, discente do Curso de Direito da UFRN e representante do Diretório Central de Estudantes, narrou as diligências efetuadas pela CV/UFRN perante as Forças Armadas do Rio Grande do Norte para fins de localização do acervo documental da extinta ASI/UFRN.

O caminho por nós trilhado guarda semelhanças com a metodologia da CV/UFRN, mas foi na memória coletiva dos agentes sociais que experienciaram o período em que a ASI/UFRN vigorou que nos amparamos mais fortemente, podendo-se asseverar que os ditos e não-ditos sobre a ASI/UFRN são mais significativos do que os próprios registros encontrados e analisados até o presente. Não se quer afirmar que o acervo documental sobre a ASI/UFRN não seja relevante do ponto de vista historiográfico. Pelo contrário. A pouca documentação existente dialoga rigorosamente com a maioria dos testemunhos prestados perante a CV/UFRN ou colhidos por nós ao longo da pesquisa. Queremos enfatizar apenas que o conteúdo oral produzido possui amplitude historiográfica mais abrangente do que a documentação encontrada, o que não é grande novidade diante da lastimável realidade da destruição dos arquivos das ASIs em todo o Brasil.

Vejamos o que disse sobre a ASI/UFRN o funcionário Leonel Ribeiro Sobrinho, que foi lotado na ASI/UFRN do campus central entre os anos de 1982 e 1985, ao depor perante a CV/UFRN:

\begin{abstract}
Olha, toda a pessoa que acessava a universidade sendo docente, técnico administrativo ou discente, ele tinha um registro, servidores docentes e técnicos através do Departamento Pessoal né.... Faziam o seu cadastro, e os discentes através do Departamento de Administração Escolar, então quando você entrava na universidade tanto no DAE quanto no Departamento Pessoal, aquele cadastro era encaminhado para a ASI, além das minhas funções de cortar jornal, isso eu sei que existia esse arquivo. Porém eu não tinha acesso a ele. Ele era de confiança do chefe da ASI... [e ficava] na sala do chefe da ASI, existia, a gente chama de arquivo, mas na realidade era cofre. (RIBEIRO SOBRINHO, 2013, p. 5).
\end{abstract}

É curioso observar a desenvoltura do colaborador da CV/UFRN ao dar detalhes da rotina administrativa da ASI/UFRN, o que seria impossível no período da ditadura. O relato oral, aliás, somente é possível em um contexto democrático, pois:

\footnotetext{
Em países de longa tradição democrática, a inscrição da prática da história oral se deu naturalmente. É fundamental, contudo, notar que em lócus (sic), com interrupções políticas autoritárias, o processo foi bem diferente daquele ocorrido em países de tradição democrática. Lá, continuidades; aqui, interrupções. [...]. Porque o registro ganhava foros de testemunho policial durante a ditadura - daí, por exemplo, o uso indiscriminado do jargão jurídico "depoimento' -, as entrevistas eram sempre evitadas, triadas por autocensura ou por censura explícita, limitadas em sua expressão livre. Como em vasta parte da América Latina, o Brasil não se eximiu dessa mácula. (MEIHY; HOLANDA, 2014, p. 109).
}

Corroborando a narrativa do servidor Leonel Ribeiro Sobrinho, a ex-aluna, exfuncionária e ex-professora da UFRN recentemente aposentada, Paula Sônia de Brito, afirmou categoricamente que "Todos os alunos e todos os professores e todos os funcionários preenchiam a ficha da ASI." (BRITO, 2017, p. 13). 
Há, porém, quem de nada sabe ou prefira silenciar a respeito do que supostamente saiba. Pelo menos foi essa a impressão que abstraímos da fala do professor Celso Luiz de Oliveira. Em seu testemunho, o professor é bastante evasivo, quase reticente. Na exposição que faz perante a Comissão da Verdade da UFRN, quando se arvorou a discorrer sobre a ASI, assim sentenciou:

Nunca ouvi falar, não tenho conhecimento, mesmo que existisse não fui notificado, nem conhecia sobre alguém ou sobre alguma comissão, de algum grupo que fizesse esse envio de informações do $\operatorname{CERES}^{15}$, nem até aqui, de colégios, de outras coisas, mas a direção geral. Não tive conhecimento. (OLIVEIRA, 2013, p. 9).

Me surpreenderam as suas afirmações há pouco. Não tive, estou pasmo com essa informação hoje do CERES, não querendo dizer que a Universidade campus central existisse, todo mundo sabia, mas aqui no CERES nesse período que eu estou de 31 de março, coincidentemente, de 82 a hoje, hoje eu não tinha, não tive e estou tendo conhecimento hoje dessas informações. (OLIVEIRA, 2013, p. 10).

Nessas passagens da fala do professor Celso Luiz de Oliveira chama a atenção a sua surpresa quanto à existência da ASI na UFRN/CERES, algo que era relativamente notório e sabido na época.

Soares (2013), em breve testemunho perante a CV/UFRN, privilegiou informações sobre a possível existência da ASI/UFRN no CERES. Afirmou que desde meados de 1980, antes mesmo de entrar no CERES como aluno (1982), ainda na condição de filiado do Partido Comunista do Brasil, já ouvira falar sobre a ASI.

Ora, desde o final da década de 1970 e mais intensamente na década de 1980, os principais veículos de imprensa do Rio Grande do Norte foram palco de considerável divulgação de matérias protagonizadas pela ASI/UFRN, nas quais se destacavam os arbítrios desse órgão de informação ${ }^{16}$.

Talvez o desconhecimento relatado por Oliveira (2013) se justifique pelo distanciamento que o próprio docente confessa quanto aos acontecimentos relacionados ao regime militar, no entanto, não podemos deixar de lembrar a característica seletiva da memória, ou seja, as pessoas lembram daquilo que podem e/ou querem lembrar:

$\mathrm{Na}$ época não se conversava muito, não tinha muita informação, a gente não procurava. [...] pouco se conversava a respeito da ditadura ou a respeito do movimento, vamos chamar assim revolucionário, principalmente no Seridó ${ }^{17}$, pois não tínhamos informações nem procurávamos saber e o pouco que a gente sabia ou tinha informações era através de algum colega só referente a "fulano de tal participou do movimento, fulano de tal foi chamado ao batalhão pra dar entrevistas" e ficava nessas conversas, a gente não se aprofundava e até porque sinceramente não nos interessava, não é que a gente desprezasse o movimento da época ou o que aconteceu naquela situação, mas por não ter aprofundamento de quem não conhecia as pessoas "ah, fulano de tal participou, fulano de tal foi preso, fulano de tal foi chamado ao batalhão". A gente ouvia, não sabia quem eram as 
pessoas, não éramos daqui e ficava só naquele conhecimento. (OLIVEIRA, 2013, p. 6).

Esse testemunho confirma a premissa de que os silenciamentos acerca dos eventos que ocorreram naquele período também se apresentam, se materializam, nas reticências, no "não dito", pois "[...] se de um lado a censura trabalha sobre o conjunto do dizível, do outro lado, em uma retórica de resistência, há uma política do silêncio que se instala (consensualmente) e que significa justamente o que, do dizível, não se pode dizer." (ORLANDI, 2007, p. 111).

A memória sobre a ASI/UFRN, de Oliveira (2013), que destoa da memória das demais testemunhas, conduziu-nos a uma reflexão em torno da memória individual e sua relação com a memória coletiva nas formulações de Halbwachs (2003). Este, ao estabelecer os parâmetros da memória coletiva, também caracterizou, secundariamente, a memória individual. Logo, acreditando que os sujeitos participam de dois tipos de memória (individual e coletiva), supõe que:

Por um lado, suas lembranças teriam lugar no contexto de sua personalidade ou de sua vida pessoal - as mesmas que lhes são comuns com outras só seriam vistas por ele apenas no aspecto que o interessa enquanto se distingue dos outros. Por outro lado, em certos momentos, ele seria capaz de se comportar simplesmente como membro de um grupo que contribui para evocar e manter lembranças impessoais, na medida em que estas interessam ao grupo. (HALBWACHS, 2003, p. 71-72).

Desenvolvendo o entendimento em torno da memória individual, diz ainda que "[...] não conseguimos lembrar senão do que vimos, fizemos, sentimos, pensamos num momento do tempo, ou seja, nossa memória não se confunde com a dos outros." (HALBWACHS, 2003, p. 72).

A despeito da singularidade da memória individual, sugere que esta guarda uma espécie de interdependência com a memória coletiva, porquanto não está isolada nem fechada em si mesma, de sorte que "Para evocar seu próprio passado, em geral a pessoa precisa recorrer às lembranças de outras, e se transporta a pontos de referência que existem fora de si, determinados pela sociedade.” (HALBWACHS, 2003, p. 72). Então,

Se a memória coletiva tira sua força e sua duração por ter como base um conjunto de pessoas, são os indivíduos que se lembram, enquanto integrantes do grupo. Desta massa de lembranças comuns, umas apoiadas nas outras, não são as mesmas que aparecerão com maior intensidade a cada um deles. De bom grado, diríamos que cada memória individual é um ponto de vista sobre a memória coletiva, que este ponto de vista muda segundo as relações que mantenho com outros ambientes. (HALBWACHS, 2003, p. 69).

Assim, a narrativa de Oliveira (2013) pode até se tratar de memória individual, porquanto experimentada apenas por ele, mas que se inserida no quadro das memórias 


\section{Revista HIIST'TEIDBR On-lime}

coletivas "se encaixaria" ao contexto geral vivido pelo grupo, como se fosse uma lembrança a mais, individualizada, mas não deslocada do complexo de memórias sobre a ASI/UFRN.

Outro aspecto da ASI/UFRN que mereceu atenção desse trabalho foi o relativo à possível existência de registros produzidos e preservados por essa assessoria de informação. Brito (2017), por exemplo, menciona que qualquer pessoa com vínculo com a UFRN era necessariamente registrada, "fichada". Restava saber onde se encontravam tais registros.

Então, quanto a possíveis registros confeccionados pela ASI/UFRN, tais como dossiês, relatórios e diligências, tem-se que, além do acervo oficial encontrado pela Comissão da Verdade da UFRN no Arquivo Nacional (Brasília), descobriu-se um fichário da ASI no CERES/UFRN, ao qual tivemos acesso. Tal fichário corresponde ao único acervo confeccionado pela ASI/UFRN cujos originais encontram-se depositados na própria UFRN. Localiza-se atualmente no Arquivo Geral do Centro de Ensino Superior do Seridó, campus Caicó/RN. Compreende 651 fichas individuais, conforme Figura 1, sendo 638 de estudantes, 2 (duas) de professores colaboradores e 11 (onze) de militares, sendo que entre as fichas destes, há 02 (duas) de alunos especiais.

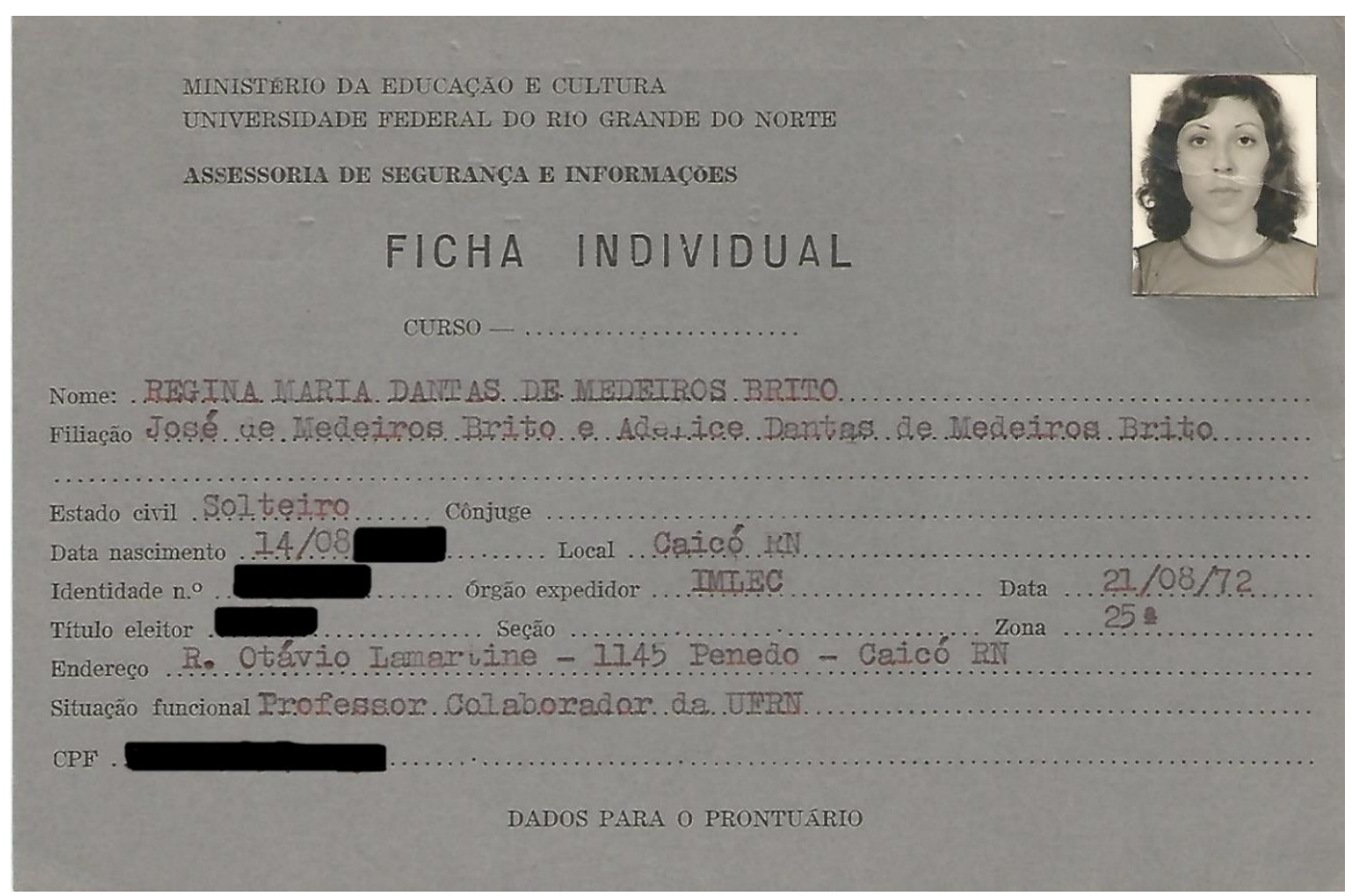

Imagem 1: Ficha Individual da ASI/UFRN - Professora.

Fonte: Arquivo do CERES/UFRN (digitalizado).

É curioso notar que à época da execução dos trabalhos da CV/UFRN nem a PróReitora de Gestão de Pessoas sabia da existência desse fichário depositado no Arquivo Geral 
do CERES/UFRN. Na verdade, nem ela nem ninguém, com exceção do atual servidor e exaluno João Inácio Soares. Conforme Almeida:

\begin{abstract}
As atividades de localização e busca do acervo documental produzido pala extinta Assessoria Especial de Segurança e Informações da UFRN foram estabelecidos desde a primeira reunião da Comissão da Verdade da Universidade Federal do Rio Grande do Norte, realizada em 26 de novembro de 2012, sob a presidência da Magnífica Reitora Ângela Maria Paiva Cruz. Naquele momento, a Pró-Reitora de Gestão de Pessoas, Sra. Miriam Dantas, afirmou que a documentação produzida pela extinta ASI-UFRN havia sido enviada a uma das unidades do Exército Brasileiro na cidade de Natal/RN. (ALMEIDA, 2015, p. 101).
\end{abstract}

Nesse sentido, relativamente aos arquivos da ASI/UFRN, “[...] seu último chefe ${ }^{18}$ e sua secretária ${ }^{19}$ são unânimes em dizer que não sabem verdadeiramente, mas ouviam dizer que foram para quartéis do exército que não sabem precisar." (BUENO, 2015, p. 96). Assim, após 19 anos (1971-1990) de existência da ASI/UFRN restaram apenas um fichário "esquecido" em um campus do interior e alguns documentos depositados no Arquivo Nacional. Sobre os acervos das assessorias de segurança e informações em particular, Motta entende que:

\begin{abstract}
O desaparecimento da documentação produzida por essas Assessorias - na verdade, em muitos casos houve destruição proposital - está longe de ser acontecimento fortuito. Aqui a expressão "queima de arquivo" assume seu pleno e literal significado. As Universidades ocupavam lugar fundamental no planejamento estratégico dos militares, por seu papel na formação das futuras elites e dos técnicos necessários à gestão da economia. Por isso o regime militar precisava obter a cooperação dos dirigentes universitários, e como as Universidades eram parte da estrutura do Estado havia meios de obter sua anuência. Quem não assentisse poderia ser punido diretamente (aposentadorias compulsórias, demissões) ou indiretamente (perda de verba, protelação no atendimento de demandas). Nas batalhas travadas em torno da construção da memória do regime militar um dos temas mais candentes é o da resistência, que gerou mitos e mistificações. Nas Universidades brasileiras houve resistência contra o autoritarismo, especialmente proveniente do movimento estudantil e sindical. Mas houve também cooperação com as políticas do Estado autoritário. Não existiu a figura do Reitor ou do Diretor crítico em relação ao regime militar, pois eles seriam afastados imediatamente. No máximo houve algum espaço para jogos ambíguos e sutis de negociação, em que alguns dirigentes universitários se empenharam em proteger certos membros da comunidade universitária, mas sempre protestando apoio ao Estado. Assim, se os documentos da maioria das AESI sumiram é porque são comprometedores. (MOTTA, 2008b, p. 33).
\end{abstract}

Quanto ao fichário “deixado" no CERES/UFRN, Soares (2013) observou que há tempos, já na condição de servidor técnico-administrativo e arquivista do CERES, havia identificado e preservado antigos arquivos da ASI, tendo-os colocado à disposição da CV/UFRN por ocasião dos trabalhos dessa Comissão.

Relativamente à possível existência de outros documentos da ASI/UFRN, em que pese as diligências da CV/UFRN, por intermédio da Reitoria, visando a busca e recolhimento de arquivos da ASI/UFRN perante as Forças Armadas norte-rio-grandenses, nenhum êxito 


\section{Revista HIISTEIDBR On-line}

foi obtido diante da negativa da detenção de acervo por parte de autoridades militares. Negaram existir arquivos da ASI/UFRN sob o poder militar o General de Brigada Carlos José Ignácio, comandante da $7^{\text {a }}$ Brigada de Infantaria Motorizada, e o Coronel Luís Antônio Ferreira Marques Ramos, comandante do $16^{\circ}$ Batalhão de Infantaria Motorizado. (UNIVERSIDADE FEDERAL DO RIO GRANDE DO NORTE, 2015, p. 109-110).

Apesar do cenário ainda em aberto sobre a ASI/UFRN diante da escassa documentação, as existentes, tais como o fichário encontrado no CERES/UFRN, apesar da aparente simplicidade das informações ali constantes, têm muito a revelar. Poderíamos citar o caso dos alunos especiais militares, possíveis informantes da ASI/UFRN e da comunidade de informação em geral, que não raro "sumiam" das salas de aula com a mesma rapidez com que nelas apareciam.

Na figura 2 encontra-se o cadastro de um provável informante. Trata-se de ficha individual de um oficial do Exército lotado, segundo as informações datilografadas pela ASI/UFRN, no $31^{\circ}$ Batalhão de Infantaria Motorizado, Caicó, e residente na vila militar desta mesma cidade.

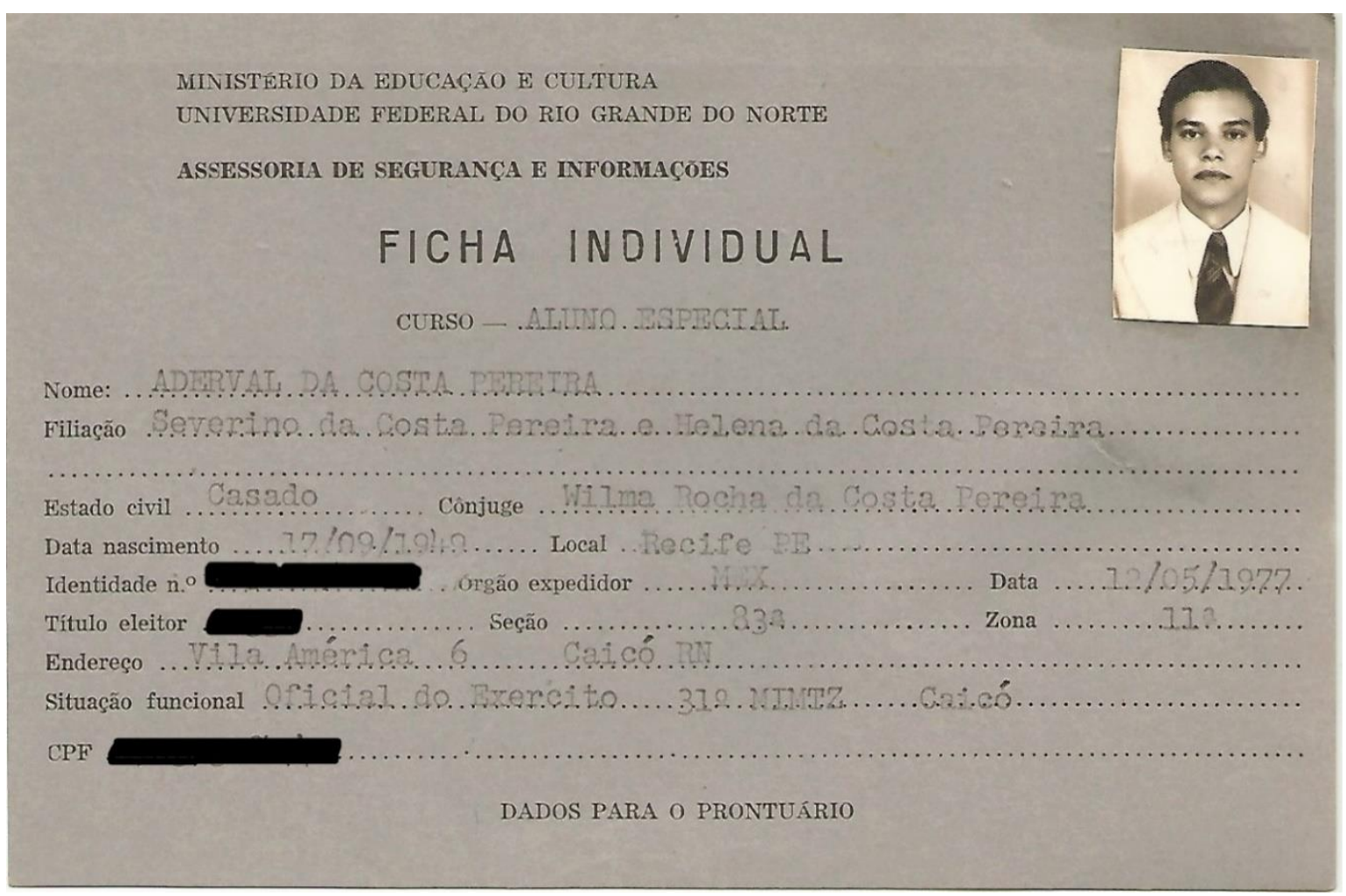

Imagem 2: Ficha Individual da ASI/UFRN - Aluno Especial, Vestibular 1978.

Fonte: Arquivo do CERES/UFRN (Digitalizado). 
Observamos que alguns dados dessa ficha e da apresentada anteriormente foram apagados e os questionamentos que fazemos são os seguintes: quando? Por quê? Na verdade, as informações apagadas identificariam os fichados local e nacionalmente.

Sobre os alunos especiais, Brito (2017, p. 15) adverte que "Era uma coisa bem disfarçada, porque eles se inscreviam como aluno especial, então a função deles não era tanto de estudar como aluno especial, e sim de ficar olhando o comportamento, não é?" Faria (2013), consolidando o raciocínio de Brito (2017), informa que:

[...] Veio a Universidade em 74, mas na Universidade aqui a gente sabia que tinha pessoas, sempre tinha um militar na sala da gente, sempre tinha... Nunca vi tanto militar estudando naquela época. Ou mulher de militar ou militar. Todas as salas de aula, em todos os cursos tinha isso. [...] eles frequentavam, mas depois a gente sabia que ele não estava matriculado normalmente no curso... Porque apareciam assim, de repente, não faziam vestibular... De repente eu estava assistindo aula de literatura e tinha militar, no curso de Letras, o que é que ele tá vendo numa aula de literatura na minha sala? (FARIA, 2013, p. 4).

Na mesma direção, vai também o testemunho de Soares (2013), que relembra com perplexidade fato marcante da sua vida universitária que envolve aluno militar:

\begin{abstract}
Quando eu era estudante de História, de repente apareceu uma pessoa. O nome dele era Flávio, uma pessoa muito educada, se infiltrou no meio acadêmico e tal, e ele saía conosco, jovem, íamos para os bares e começávamos a discutir política. [...] ele participava de todas as discussões. E uma vez eu fui para Recife de ônibus e depois eu me encontrei com esse rapaz fazendo uma fiscalização, daí foi que eu descobri que ele era policial. (SOARES, 2013, p. 4).
\end{abstract}

Essa fala de Soares (2013) abona as afirmações de Faria (2013), de que havia alunos militares em sala de aula, sendo os mesmos prováveis informantes de acordo com o contexto em que aparecem nos testemunhos. Como afirmamos, somente entre os anos 1974 e 1979, encontram-se registrados 11 (onze) militares discentes nas fichas individuais da ASI/UFRN do campus de Caicó, sendo 9 (nove) com matrículas regulares em cursos e 2 (dois) na condição de alunos especiais.

Há outras perspectivas que, em aprofundamento posterior por meio de estudos em torno das Assessorias de Segurança e Informação regionalmente consideradas, podem ser tratadas, a exemplo da posição dos reitorados em face dos mandos e desmandos das ASI nos campi do interior e da colaboração de membros do corpo docente e discente com a comunidade de informação via assessorias. Para o momento, em função da análise mais adequada ao modelo de artigos científicos, optamos por abordar situações mais notáveis do ponto de vista da atuação de um órgão de informação (ASI/UFRN) que, assim como os demais, tinha como uma das principais missões não deixar registros dos seus atos para a posteridade.

Tomando por empréstimo a síntese de Bueno (2015) sobre o que foi a ASI/UFRN do seu apogeu (1971) ao seu ocaso (1990): 
O que podemos extrair de mais significativo da experiência da ASI na UFRN é que, durante certo tempo, a rigor, nos anos de chumbo da ditadura, ela teve livre trânsito para cumprir suas tarefas de delação e controle sobre os estudantes, professores e funcionários da UFRN, com o beneplácito explícito ou velado dos reitores aos quais oficialmente estava subordinada [...]. A partir do momento em que os ventos da redemocratização se tornaram mais fortes e os generais foram recuando lentamente às casernas, a ASI perdeu o sentido de sua existência e caminhou definhando até sua extinção. (BUENO, 2015, p. 96).

No dia 14 de outubro de 2015, por ocasião do lançamento do Relatório Final da Comissão da Verdade UFRN, foi aposta, no prédio da Reitoria, uma placa simbólica alusiva à extinção da Assessoria de Segurança e Informação da UFRN. Para nunca mais.

\section{CONSIDERAÇÕES FINAIS}

No contexto da proposta inaugural deste trabalho, que intentou refletir sobre a cooperação existente entre as universidades e a comunidade de informação do regime militar para fins de monitoramento da vida acadêmica, seguem as ponderações que alcançamos, no contexto de uma investigação que possui uma divisa: a própria de um artigo científico, cuja discussão acha-se limitada a certo número de páginas e a prazos previamente estabelecidos.

Sob um olhar panorâmico, não é possível calcular a amplitude dos prejuízos advindos dos longos anos em que as Assessorias de Segurança e Informação (ASI) das universidades brasileiras atuaram em concurso com a comunidade de informação do regime militar. Sabese, no entanto, que não foram poucos os excessos e que há muito ainda a ser desvelado quanto aos efeitos deletérios de um serviço de informação que, em última instância, viabilizou também a repressão, ao "informar" (escolher) quem deveria ser alvo dos mais variados arbítrios dos órgãos de repressão do Estado autoritário.

$\mathrm{Na}$ esteira do que Motta (2008a; 2008b; 2014) constatara, com raras atenuações dependentes dos mandatários das reitorias, as atividades das ASI e a postura dos seus chefes universitários resultaram: na supressão da liberdade nos campus, na inauguração de um ambiente de medo e insegurança - que de alguma forma persiste até o momento atual - , no boicote à produção científica e à pós-graduação, no depauperamento do debate políticoacadêmico, no impedimento e frustração da carreira docente, na perseguição indiscriminada da comunidade acadêmica militante e, em última análise, na tentativa de aniquilamento do direito à memória e à verdade quando do desvio, ocultação e destruição dos arquivos das ASI por todo o Brasil.

Documentos, dossiês, relatórios, diligências etc. podem até ter sido condenados à flama incendiária dos agentes de informação ou relegados a ocupar um lugar de desonra em covis das Forças Armadas, mas a memória coletiva, encrustada em todos e em cada um daqueles que foram alvos dos arbítrios da ASI, nunca se apagou. Foi a ela que recorremos prioritariamente para constituir uma narrativa possível. 
Nessa perspectiva, pode-se atribuir à ASI/UFRN os efeitos danosos acima apontados da existência legal, mas imoral e ilegítima, de um órgão da comunidade de informação da ditadura no seu campus central e nos campi do interior. Aliás, foi exatamente em um dos seus campi do interior, o CERES/UFRN, que foi encontrado o único registro original sobre a ASI/UFRN depositado na própria instituição. Trata-se das 651 (seiscentos e cinquenta e uma) fichas individuais da ASI/UFRN, que se prestaram ao monitoramento dos novos ingressantes e ao cadastro de alguns "alunos especiais", concidentemente militares.

Muito do que foi "desvelado" nesta e em outras investidas acerca da atuação das ASI nas universidades, não seria possível sem a utilização da metodologia da história oral, que viabilizou a constituição de uma narrativa cujo conteúdo verte a memória coletiva da comunidade acadêmica alvo de tais assessorias, a exemplo da ASI/UFRN. Da mesma forma, sem o instinto de caça próprio do indiciarismo ginzburguiano, que pode ser, sim, aprendido e apreendido, teriam sido deixados de lados os vestígios, os rastros que levaram, por exemplo, ao fichário da ASI/UFRN arquivado no CERES/UFRN.

Tratou-se, portanto, de trabalho em que objeto e metodologia se fundiram para proporcionar não somente novas descobertas, mas para fortalecer o próprio ato de investigar. É ainda uma pesquisa inconclusa, porém pela relevância do tema de que se ocupou, espera reunir-se a tantos outros trabalhos dessa ordem que, nas linhas e entrelinhas, conclamam pelo direito à memória e à verdade e pelo desfecho de qualquer intento autoritário saudosista, próprio dos dias atuais.

Por último, e não perdendo de vista a perspectiva histórica do nosso tempo, percebemos a relevância de investigações dessa natureza, tanto para inibir possíveis retomadas, como para possibilitar a narração do inenarrável, do indescritível, daquilo que a lacuna histórica não conseguiu preencher. A trajetória das testemunhas, seus ditos e nãoditos, seus silêncios, lembra-nos, as escrituras sobre Auschwitz, e especialmente Wiesel (apud AGAMBEN, 2008, p. 42), em sua reflexão: "Os que não viveram aquela experiência nunca saberão o que ela foi; os que a viveram nunca o dirão; realmente não, não até o fundo." Nessa configuração, as testemunhas da CV/UFRN e os colaboradores desse trabalho falam do que podem falar, narram o narrável, o dizível, mas "não até o fundo". Mesmo assim, a memória continua fazendo seu trabalho de rememorar o passado e de recuperar seus rastros, apesar dos brancos e lacunas dos testemunhos. Nesse contexto, a UFRN segue sua trajetória educacional e as jovens gerações que a ela têm acesso, possivelmente, não "[...] crescerão em uma espécie de presente contínuo.” (HOBSBAWM, 1995, p. 13).

\section{REFERÊNCIAS}

AGAMBEN, G. O que resta de Auschwitz: o arquivo e a testemunha. (Homo Sacer III). Tradução Selvino J. Assmann. São Paulo: Boitempo, 2008. (Estado de sítio). 


\section{Revista HIISTEIDBR On-line}

ISSN: 1676-2584

Artigo

doi: $10.20396 /$ rho.v18i1.8651655

ALMEIDA, J. A. Diligências para localização do acervo documental da extinta assessoria de segurança e informações da UFRN (1970-1990). In: Universidade Federal do Rio Grande do Norte. Comissão da verdade da UFRN: relatório final. Natal: Ed. da UFRN, 2015. p. 101-113.

ALVES FILHO, G. Universidade e repressão. Tribuna do Norte. Natal, 18 maio 1985. Disponível em: <http://bczm.ufrn.br/comissaodaverdade/ENT.\%20DE\%20REP.\%20 ESTUDANTIL-JORNAIS\%20DIVERSOS\%20(1978-1986)\%20\%e2\% 80\%93\%20 (CAIXA\%2005)/JORNAIS\%20DIVERSOS\%20(1978-1986)/>. Acesso em: 10 set. 2017.

ASI começa a ser desativada na UFRN e comunidade universitária aplaude. Tribuna do Norte. Natal, 20 jul. 1985. Disponível em: <http://bczm.ufrn.br/comissaodaverdade/ ENT.\%20DE\%20REP.\%20ESTUDANTIL-JORNAIS\%20DIVERSOS\%20(19781986)\%20\% $2 \% 80 \% 93 \% 20($ CAIXA\%2005)/JORNAIS\%20DIVERSOS\%20(19781986)/>. Acesso em: 10 set. 2017.

ASI e liberação de verbas na agenda de Genibaldo. A República. Natal, 19 jun. 1985. Política, p. 3. Disponível em: <http://bczm.ufrn.br/comissaodaverdade/ENT.\%20DE \%20REP.\%20ESTUDANTIL-JORNAIS\%20DIVERSOS\%20(1978-1986)\%20\% e2\% 80\%93\%20(CAIXA\%2005)/JORNAIS\%20DIVERSOS\%20(1978-1986)/>. Acesso em: 10 set. 2017.

ASI está deixando a Universidade Federal. Tribuna do Norte. Natal, 21 jul. 1985. Disponível em: <http://bczm.ufrn.br/comissaodaverdade/ENT.\%20DE\%20REP.\% 20ESTUDANTIL-JORNAIS\%20DIVERSOS\%20(1978-1986)\%20\%e2\%80\%93\%20 (CAIXA\%2005)/JORNAIS\%20DIVERSOS\%20(1978-1986)/>. Acesso em: 10 set. 2017.

ASI: informação e espionagem na UFRN. Tribuna do Norte. Natal, 26 jun. 1985. Disponível em: <http://bczm.ufrn.br/comissaodaverdade/ENT.\%20DE\%20REP.\% 20ESTUDANTIL-JORNAIS\%20DIVERSOS\%20(1978-1986)\%20\% 2\%80\%93\%20 (CAIXA\%2005)/JORNAIS\%20DIVERSOS\%20(1978-1986)/>. Acesso em: 10 set. 2017.

ASI muda de endereço. Tribuna do Norte. Natal, 23 jul. 1985. Disponível em: <http://bczm.ufrn.br/comissaodaverdade/ENT.\%20DE\%20REP.\%20ESTUDANTILJORNAIS\%20DIVERSOS\%20(1978-1986)\%20\%e2\%80\%93\%20(CAIXA\%2005)/ JORNAIS\%20DIVERSOS\%20(1978-1986)/>. Acesso em 10 set. 2017.

ASSEMBLÉIA tomará posição sobre ASI. A República. Natal, 6 mar. 1980. Disponível em: <http://bczm.ufrn.br/comissaodaverdade/ENT.\%20DE\%20REP.\%20ESTUDANTILJORNAIS\%20DIVERSOS\%20(1978-1986)\%20\%e2\%80\%93\%20(CAIXA\%2005)/ JORNAIS\%20DIVERSOS\%20(1978-1986)/>. Acesso em: 10 set. 2017.

BERGSON, H. Matéria e memória: ensaio sobre a relação do corpo com o espírito. Tradução Paulo Neves. 2. ed. São Paulo: Martins Fontes, 1999.

BOSI, E. Memória e sociedade: lembranças de velhos. 3. ed. São Paulo: Companhia das Letras, 1994. 
Artigo

doi: $10.20396 /$ rho.v18i1.8651655

BRASIL. Lei n. 12.527, de 18 de novembro de 2011. Regula o acesso a informações previsto no inciso XXXIII do art. 5o, no inciso II do § 3o do art. 37 e no § 2o do art. 216 da Constituição Federal; altera a Lei no 8.112, de 11 de dezembro de 1990; revoga a Lei no 11.111, de 5 de maio de 2005, e dispositivos da Lei no 8.159, de 8 de janeiro de 1991; e dá outras providências. Disponível em: <http://www.planalto.gov.br/ccivil_03/_ato20112014/2011/lei/112527.htm>. Acesso em: 07 ago. 2017.

BRASIL. Lei n. 12.528, de 18 de novembro de 2011. Cria a Comissão Nacional da Verdade no âmbito da Casa Civil da Presidência da República. Disponível em: <http:// www.planalto.gov.br/ccivil_03/_Ato2011-2014/2011/Lei/L12528.htm>. Acesso em: 07 jul. 2016.

BRITO, P. S. de. Paula Sônia de Brito: testemunho [19 out. 2017]. Testemunho concedido a Rogério de Araújo Lima. Natal/RN, 2017.

BUENO, A. C. A assessoria de segurança e informações do Ministério da Educação e Cultura (MEC) na Universidade Federal do Rio Grande do Norte (ASI/UFRN): o braço da repressão nas universidades brasileiras. In: Universidade Federal do Rio Grande do Norte. Comissão da verdade da UFRN: relatório final. Natal: Ed. da UFRN, 2015. p. 85-100.

DEPENDE da ASI nomeação de diretores de centros da UFRN. Dois Pontos. Natal, 4 nov. 1983. Disponível em: <http://bczm.ufrn.br/comissaodaverdade/ENT.\%20DE\%20REP.\% 20ESTUDANTIL-JORNAIS\%20DIVERSOS\%20(1978-1986)\%20\% $2 \% 80 \% 93 \% 20$ (CAIXA\%2005)/JORNAIS\%20DIVERSOS\%20(1978-1986)/>. Acesso em: 10 set. 2017.

DEPUTADOS pedem extinção da ASI na Universidade. Tribuna do Norte. Natal, 18 maio 1985. Disponível em: <http://bczm.ufrn.br/comissaodaverdade/ENT.\%20DE\%20 REP.\%20ESTUDANTIL-JORNAIS\%20DIVERSOS\%20(1978-1986)\%20\% 2\%80\%93\% 20(CAIXA\%2005)/JORNAIS\%20DIVERSOS\%20(1978-1986)/>. Acesso em: 10 set. 2017.

ESTUDANTES insistem no desaparecimento da ASI. Diário de Natal. Natal, 5 jul. 1979. Disponível em: <http://bczm.ufrn.br/comissaodaverdade/ENT.\%20DE\%20REP.\%20 ESTUDANTIL-JORNAIS\%20DIVERSOS\%20(1978-1986)\%20\% 2\%80\%93\%20 (CAIXA\%2005)/JORNAIS\%20DIVERSOS\%20(1978-1986)/>. Acesso em: 10 set. 2017.

EXTINÇÃO da ASI é pedida na Universidade. Tribuna do Norte. Natal, 4 jun. 1985. Disponível em: <http://bczm.ufrn.br/comissaodaverdade/ENT.\%20DE\%20REP.\% 20ESTUDANTIL-JORNAIS\%20DIVERSOS\%20(1978-1986)\%20\% $2 \% 80 \% 93 \% 20$ (CAIXA\%2005)/JORNAIS\%20DIVERSOS\%20(1978-1986)/>. Acesso em: 10 set. 2017.

FARIA, D. R. de. Dirceu Ribeiro de Faria: testemunho [05 jun. 2013]. Testemunho concedido à Comissão da Verdade da Universidade Federal do Rio Grande do Norte. Caicó/RN, 2013. Disponível em: <http://bczm.ufrn.br/comissaodaverdade/DEPOENTES \%20CV-UFRN\%20(CAIXAS\%2003A\%20e\%2003B)/DEPOENTES\%20-\%20CAIXA\% 2003A/DIRCEU\%20RIBEIRO/>. Acesso em: 07 jul. 2016. 
FICHA individual da ASI/UFRN - Aluno especial, vestibular 1978. Caicó, RN: Arquivo do CERES/UFRN, 1978. 1 imagem digitalizada.

FICHA individual da ASI/UFRN - Professora. Caicó, RN: Arquivo do CERES/UFRN, 1972. 1 imagem digitalizada.

FIGUEIREDO, L. Lugar nenhum: militares e civis na ocultação dos documentos da ditadura. São Paulo: Companhia da Letras, 2015.

GARIBALDI contra a ASI na Universidade. Tribuna do Norte. Natal, 18 maio. 1985. Disponível em: <http://bczm.ufrn.br/comissaodaverdade/ENT.\%20DE\%20REP.\%20 ESTUDANTIL-JORNAIS\%20DIVERSOS\%20(1978-1986)\%20\%e2\%80\%93\%20 (CAIXA\%2005)/JORNAIS\%20DIVERSOS\%20(1978-1986)/>. Acesso em: 10 set. 2017.

GINZBURG, C. Sinais: raízes de um paradigma indiciário. In: GINZBURG, C. Mitos, emblemas, sinais: morfologia e história. 2. ed. Tradução de Federico Carotti. São Paulo: Companhia das Letras, 1989. p. 143-179.

HALBWACHS, M. A memória coletiva. Tradução de Beatriz Sidou. 2. ed. São Paulo: Centauro, 2003.

HOBSBAWM, E. O século: vista aérea. In: HOBSBAWM, E. Era dos extremos: o breve século XX: 1914-1991. São Paulo: Companhia das Letras, 1995. p. 11-15.

HOUAISS, A.; VILLAR, M. S. Dicionário Houaiss da língua portuguesa. Rio de Janeiro: Objetiva, 2009.

LIMA, H. E. Con il poco farete assai: a microstoria de Carlo Ginzburg. In: LIMA, H. E. A micro-história italiana: escalas, indícios e singularidades. Rio de Janeiro: Civilização Brasileira, 2006. p. 277-363.

LOZANO, J. E. A. Prática e estilos de pesquisa na história oral contemporânea. In:

FERREIRA, M. de. M.; AMADO, J. (Org.). Usos \& abusos da história oral. 8. ed. Rio de Janeiro: FGV, 2006. p. 15-25.

MEC começa estudo sobre situação da ASI na UFRN. A República. Natal, 25 jun. 1985, p. 7. Disponível em: <http://bczm.ufrn.br/comissaodaverdade/ENT.\%20DE\%20REP.\%20 ESTUDANTIL-JORNAIS\%20DIVERSOS\%20(1978-1986)\%20\%e2\%80\%93\%20 (CAIXA\%2005)/JORNAIS\%20DIVERSOS\%20(1978-1986)/>. Acesso em: 10 set. 2017.

MEIHY, J. C. S. B; HOLANDA, F. História oral: como fazer, como pensar. 2. ed. São Paulo: Contexto, 2014.

MOTTA, R. P. S. As universidades e o regime militar: cultura política brasileira e modernização autoritária. São Paulo: Zahar, 2014. 
MOTTA, R. P. S. Incômoda memória: os arquivos da ASI universitárias. Acervo, Rio de Janeiro, v. 21, n. 2, p. 43-66, jul./dez. 2008a. Disponível em: <http://revista.arquivo nacional.gov.br/index.php/revistaacervo/article/view/294/294>. Acesso em: 5 maio 2017.

MOTTA, R. P. S. Os olhos do regime militar brasileiro nos campi: as assessorias de segurança e informações das universidades. Topoi, Rio de Janeiro, v. 9, n. 16, p. 30-67, jan./jun. 2008b. Disponível em: <http://dx.doi.org/10.1590/2237-101X009016002〉. Acesso em: 5 maio 2017.

OLIVEIRA, C. L. de. Celso Luiz de Oliveira: testemunho [17 set. 2013]. Testemunho concedido à Comissão da Verdade da Universidade Federal do Rio Grande do Norte. Caicó/RN, 2013. Disponível em: <http://bczm.ufrn.br/comissaodaverdade/ DEPOENTES $\%$ 20CV-UFRN\%20(CAIXAS\%2003A\%20e\%2003B)/DEPOENTES\%20-\%20CAIXA\% 2003A/CELSO\%20LU\%c3\%8dZ\%20DE\%20OLIVEIRA/>. Acesso em: 07 jul. 2016.

ORLANDI, E. P. As formas do silêncio: no movimento dos sentidos. 6. ed. Campinas/SP: Ed. da UNICAMP, 2007.

RIBEIRO SOBRINHO, L. Leonel Ribeiro Soares: testemunho [05 ago. 2013]. Testemunho concedido à Comissão da Verdade da Universidade Federal do Rio Grande do Norte. Caicó/RN, 2013. Disponível em: <http://bczm.ufrn.br/comissaodaverdade/ DEPOENTES\%20CV-UFRN\%20(CAIXAS\%2003A\%20e\%2003B)/DEPOENTES\%20\%20CAIXA\%2003B/LEONEL\%20RIBEIRO\%20SOBRINHO/Transcri\%c3\%a7\%c3\%a3 o-\%20Leonel\%20Ribeiro\%20Sobrinho_2.8.2013.pdf>. Acesso em: 12 jul. 2016.

SÓ A SIGLA “ASI” causa temor nos universitários. Diário de Natal. Natal, 4 ago. 1979. Disponível em: <http://bczm.ufrn.br/comissaodaverdade/ENT.\%20DE\%20REP.\%20 ESTUDANTIL-JORNAIS\%20DIVERSOS\%20(1978-1986)\%20\% $2 \% 80 \% 93 \% 20$ (CAIXA\%2005)/JORNAIS\%20DIVERSOS\%20(1978-1986)/>. Acesso em: 10 set. 2017.

SOARES, J. I. João Inácio Soares: testemunho [05 jun. 2013]. Testemunho concedido à Comissão da Verdade da Universidade Federal do Rio Grande do Norte. Caicó/RN, 2013. Disponível em: <http://bczm.ufrn.br/comissaodaverdade/DEPOENTES\%20CV-UFRN $\%$ 20(CAIXAS $\% 2003$ A $\% 20 \mathrm{e} \% 2003 \mathrm{~B}$ )/DEPOENTES $\% 20-\% 20 \mathrm{CAIXA} \% 2003 \mathrm{~B} / \mathrm{JOS} \%$ c3\%89\%20IN\%c3\%81CIO\%20E\%20JO\%c3\%83O\%20DUTRA/>. Acesso em: 07 jul. 2016.

UNIVERSIDADE FEDERAL DO RIO GRANDE DO NORTE. UFRN. Comissão da verdade da UFRN: relatório final. Natal: Ed. da UFRN, 2015.

UNIVERSIDADE FEDERAL DO RIO GRANDE DO NORTE. UFRN. Portaria $\mathrm{n}^{\circ}$ 1.809/12-R, de 31 de outubro de 2012. Boletim de Serviço da UFRN, Natal, RN, n. 209, 8 nov. 2012 , f. 3. 


\section{Revista HIISTESIBR Dn-lime}

Notas

${ }^{1}$ Doutorado em Educação pela Universidade Federal do Rio Grande do Norte. Professora Associada da Universidade Federal da Paraíba. Departamento de Fundamentação da Educação. Centro de Educação. Credenciada aos Programas de Pós-Graduação em Educação - PPGE e em Direitos Humanos - PPGDH. Pesquisadora dos Grupos de Estudos e Pesquisas História da Educação Brasileira - HISTEDBR - GT -PB e Memória, História e Educação. E-mail: mecarvalho23@yahoo.com.br.

2 Professor Adjunto II do Departamento de Direito do Centro de Ensino Superior do Seridó (CERES), da Universidade Federal do Rio Grande do Norte (UFRN). Bacharel em Direito pela Universidade Federal da Paraíba (UFPB). Mestre em Ciências Jurídicas pela Universidade Federal da Paraíba (UFPB). Doutorando em Educação (UFPB). E-mail: rogeriolimaufrn@gmail.com.

${ }^{3}$ Sistema Nacional de Informação.

${ }^{4}$ Centro de Informação do Exército ou Centro de Inteligência do Exército (a partir de 1993).

${ }^{5}$ Centro de Informações de Segurança da Aeronáutica.

${ }^{6}$ Centro de Informações de Segurança da Aeronáutica.

${ }^{7}$ Conferir, a respeito: FIGUEIREDO, Lucas. Lugar nenhum: militares e civis na ocultação dos documentos da ditadura. São Paulo: Companhia da Letras, 2015.

8 José Sarney (1985-1990), Fernando Collor de Melo (1990-1992), Itamar Franco (1992-1995), Fernando Henrique Cardoso (1995-1999 e 1999-2003), Luís Inácio Lula da Silva (2003-2007 e 2007-2011) e Dilma Rousseff (2011-2015 e 2015-2016).

${ }^{9}$ Lei $\mathrm{n}^{\circ}$ 12.527, de 18 de novembro de 2011, que "Regula o acesso a informações previsto no inciso XXXIII do art. 5o, no inciso II do $\S 30$ do art. 37 e no $\S 20$ do art. 216 da Constituição Federal; altera a Lei no 8.112, de 11 de dezembro de 1990; revoga a Lei no 11.111, de 5 de maio de 2005, e dispositivos da Lei no 8.159, de 8 de janeiro de 1991; e dá outras providências.” (BRASIL, 2016, p. 1).

${ }^{10}$ Lei n ${ }^{\circ} 12.528$, de 18 de novembro de 2011, que "Cria a Comissão Nacional da Verdade no âmbito da Casa Civil da Presidência da República.” (BRASIL, 2017, p. 1).

${ }^{11}$ Para Bergson (1999), a memória, sempre presente, perene e virtualmente concebida, tem o mister de articular o passado e o presente como uma demanda atual deste. Na verdade, o filósofo francês fala em memórias no plural, nos seguintes termos: "Há, dizíamos, duas memórias profundamente distintas: uma, fixada no organismo, não é senão o conjunto dos mecanismos inteligentemente montados que asseguram uma réplica conveniente às diversas interpelações possíveis. Ela faz com que nos adaptemos à situação presente, e que as ações sofridas por nós se prolonguem por si mesmas em reações ora efetuadas, ora simplesmente nascentes, mas sempre mais ou menos apropriadas. Antes hábito do que memória, ela desempenha nossa experiência passada, mas não evoca sua imagem. A outra é a memória verdadeira. Coextensiva à consciência, ela retém e alinha uns após outros todos os nossos estados à medida que eles se produzem, dando a cada fato seu lugar e consequentemente marcando-lhe a data, movendo-se efetivamente no passado definitivo, e não,como a primeira, num presente que recomeça a todo instante.” (BERGSON, 1999, p. 176-177).

${ }^{12}$ Departamento de Ordem Política e Social.

${ }^{13}$ Destacamento de Operações Internas - Centro de Operações de Defesa Interna.

14 Nesse contexto, cabe uma advertência quanto ao pioneirismo dos estudos em torna da temática das Assessorias de Segurança e Informações no Brasil. A primeira menção que registramos sobre tais assessorias encontra-se em dois ensaios bem anteriores ao lançamento do Relatório Final da Comissão da Verdade da UFRN. Trata-se do primeiro debate mais significativo sobre as assessorias de segurança e informações nas universidades, da autoria de Motta (2008a; 2008b), decorrentes da análise de raro acervo encontrado nos Arquivos Públicos dos Estados de São Paulo e Rio de Janeiro (acervos DOPS), no Centro de Documentação da Universidade de Brasília (UnB), na Biblioteca Central da Universidade Federal de Minas Gerais (UFMG) e, mais adiante, no Arquivo Nacional. Pode-se dizer que esses trabalhos inauguram de forma sistematizada o debate acerca das ASI nas universidades. Seis anos depois, com a abertura/descoberta de novos acervos, Motta (2014) atualiza a pesquisa sobre as ASI em capítulo próprio do seu livro "As Universidades e o Regime Militar", capítulo esse intitulado "Os espiões nos campi”, no qual versa sobre a comunidade de informações, contrapropaganda, anticomunismo, combate à corrupção, censura e controle da vida universitária, triagem ideológica e ineficiência e corrupção nas ASI.

${ }^{15}$ Centro de Ensino Superior do Seridó, campus Caicó/RN e Currais Novos/RN.

${ }^{16}$ Os jornais Diário de Natal (1979), Dois Pontos (1979; 1983), A República (1980; 1985) e Tribuna do Norte (1985) somam juntos pelo menos catorze artigos sobre a ASI/UFRN, o que indica o conhecimento da existência 


\section{Revista HIIST'THDIBR On-line}

desse órgão não só pela comunidade acadêmica da UFRN, mas pela população norte-rio-grandense em geral. Vejamos os títulos dos artigos encontrados: Universidade e repressão (2017); ASI começa a ser desativada na UFRN e comunidade universitária aplaude (2017); ASI e liberação de verbas na agenda de Genibaldo (2017); ASI está deixando a Universidade Federal (2017); ASI muda de endereço (2017); ASI: informação e espionagem na UFRN(2017); Assembléia tomará posição sobre ASI (2017); Depende da ASI nomeação de diretores de centros da UFRN (2017); Deputados pedem extinção da ASI na Universidade (2017); Estudantes insistem no desaparecimento da ASI (2017); Extinção da ASI é pedida na Universidade (2017); Garibaldi contra a ASI na Universidade (2017); MEC começa estudo sobre situação da ASI na UFRN (2017); Só a sigla "ASI" causa temor nos universitários (2017). As informações completas sobre tais artigos poderão ser consultadas nas Referências desse trabalho.

${ }^{17}$ Refere-se ao semiárido norte-rio-grandense, em particular à cidade de Caicó/RN, onde está sediado o campus no qual leciona (CERES/UFRN/Campus Caicó).

${ }^{18}$ Coronel José Renato Leite.

${ }^{19}$ Aracy Siqueira.

Submetido em: 08/02/2018

Aprovado em: 24/03/2018

Publicado em: 02/04/2018 